\title{
Role of the progesterone receptor for paclitaxel resistance in primary breast cancer
}

\author{
M Schmidt', E Bremer', D Hasenclever², A Victor ${ }^{3}$, M Gehrmann 4 , E Steiner', IB Schiffer', S Gebhardt', \\ H-A Lehr', M Mahlke', M Hermes ${ }^{6,7}$, A Mustea ${ }^{8}$, B Tanner', H KoelbI', H Pilch' and JG Hengstler ${ }^{*, 6,7}$ \\ 'Department of Obstetrics \& Gynecology, Medical School, University of Mainz, Mainz, Germany; ${ }^{2}$ Coordinating Center for Clinical Trials, University of \\ Leipzig, Leipzig, Germany; ${ }^{3}$ Institute of Medical Biometry, Epidemiology and Information Science, University of Mainz, Mainz, Germany; ${ }^{4}$ Bayer Health \\ Care, Leverkusen, Germany; ${ }^{5}$ Institute of Pathology, Johannes Gutenberg University, Mainz, Germany; ${ }^{6}$ Center for Toxicology, University of Leipzig, \\ Haertelstr. 16-1 8, 04107 Leipzig, Germany; ${ }^{7}$ Leibniz Research Centre for Working Environment and Human Factors, University of Dortmund, Dortmund, \\ Germany; ${ }^{8}$ Department of Obstetrics and Gynecology, Charite, Berlin, Germany; ${ }^{9}$ Department of Obstetrics and Gynecology, University of Leipzig, Philipp- \\ Rosenthal-Str. 55, 04103 F Leipzig, Germany
}

Paclitaxel plays an important role in the treatment of primary breast cancer. However, a substantial proportion of patients treated with paclitaxel does not appear to derive any benefit from this therapy. We performed a prospective study using tumour cells isolated from 50 primary breast carcinomas. Sensitivity of primary tumour cells to paclitaxel was determined in a clinically relevant range of concentrations $\left(0.85-27.2 \mu \mathrm{g} \mathrm{ml}^{-1}\right.$ paclitaxel) using an ATP assay. Chemosensitivity data were used to study a possible association with immunohistochemically determined oestrogen and progesterone receptor (ER and PR) status, as well as histopathological parameters. Progesterone receptor (PR) mRNA expression was also determined by quantitative RT-PCR. We observed a clear association of the PR status with chemosensitivity to paclitaxel. Higher levels of immunohistochemically detected PR expression correlated with decreased chemosensitivity $(P=0.008)$. Similarly, high levels of PR mRNA expression were associated with decreased paclitaxel chemosensitivity $(P=0.007)$. Cells from carcinomas with T-stages 3 and 4 were less sensitive compared to stages $I$ and $2(P=0.013)$. Multiple regression analysis identified PR receptor status and T-stage as independent predictors of paclitaxel chemosensitivity, whereas the $\mathrm{ER}, \mathrm{N}$-stage, grading and age were not influential. In conclusion, in vitro sensitivity to paclitaxel was higher for PR-negative compared with PR-positive breast carcinoma cells. Thus, PR status should be considered as a possible factor of influence when designing new trials and chemotherapy protocols.

British Journal of Cancer (2007) 96, 24I-247. doi:I0.1038/sj.bjc.6603538 www.bjcancer.com

Published online 9 January 2007

(c) 2007 Cancer Research UK

Keywords: paclitaxel; chemosensitivity; primary tumour cells; individualized chemotherapy; progesterone receptor

Taxanes like paclitaxel play an important role in the adjuvant treatment of breast cancer (Henderson et al, 2003). The efficacy of paclitaxel containing treatment can be further improved by dose dense protocols in which the chemotherapy is administered every 2 weeks with G-CSF support. Arguably, sequential protocols in which paclitaxel is administered not only dose dense, but also dose intensified, might prove to be even more efficient. Despite the well-documented antitumour efficacy of paclitaxel, many tumours exhibit intrinsic resistance to paclitaxel. These patients will obviously not profit from addition of paclitaxel to an anthracycline-based adjuvant chemotherapy. Identifying these patients could not only spare them an ineffective treatment, but gives the opportunity to establish a more efficient protocol for this particular subgroup of paclitaxel-resistant patients. In the adjuvant setting, Henderson et al (2003) have shown that especially patients whose tumours were oestrogen receptor (ER) negative derived

*Correspondence: Professor JG Hengstler;

E-mail: jan.hengstler@medizin.uni-leipzig.de

The study has not been presented elsewhere

Received 24 July 2006; revised 23 August 2006; accepted 20 November 2006; published online 9 January 2007 most of the benefit from adding paclitaxel to an anthracyclin-based regimen. However, it is not entirely clear whether in this setting the prognostic impact of the hormone receptor status and the effect of adjuvant treatment with tamoxifen might thus offset a potential predictive effect of the hormone receptor status for paclitaxel chemosensitivity.

A large number of studies have been performed to identify predictive markers for chemosensitivity and/or prognosis of carcinomas (Hengstler et al, 1992, 2001; Micke et al, 2001, 2003; Brenner et al, 2002; Hast et al, 2002; Schiffer et al, 2003; Steiner et al, 2003; Mohrmann et al, 2005). Resistance to paclitaxel can be induced by decreased expression of the spindle assembly checkpoint genes Mad2 and BubR1 (Sudo et al, 2004). In contrast, low expression of the microtubule-associated protein tau was associated with high sensitivity to paclitaxel (Rouzier et al, 2005). High expression of beta-tubulin III has been reported to predict progression after paclitaxel chemotherapy (Paradiso et al, 2005). Thus, genes involved in spindle assembly have a high probability to be involved in paclitaxel resistance. This corresponds to the mechanism of action, as paclitaxel stabilises microtubules. Resistance to paclitaxel (Duan et al, 2005) and docetaxel (Chang et al, 2003) has been reported to be associated with specific 
242

patterns of gene expression. Interestingly, chemosensitivity of primary tumour cells could be increased by inhibition of Pglycoprotein (Di Nicolantonio et al, 2004). These examples demonstrate that many factors that might predict paclitaxel chemosensitivity of breast cancer patients have been discovered. If validated, these factors could help to reduce unnecessary treatment for women with breast cancer or help to identify sensitive subpopulations. An important milestone in translation of preclinical concepts to clinical application is the demonstration that new predictive factors are independent from the classical histopathological parameters. However, the influence of histopathological factors, such as ER and PR status, T-stage, N-stage, grading and patient's age on paclitaxel chemosensitivity of the breast carcinoma cells is still not clear. To clarify this controversial issue, we performed a prospective study in 53 consecutive breast cancer patients using an in vitro chemosensitivity assay (ATPTCA, Andreotti et al, 1995; Kurbacher et al, 1996; Hengstler et al, $1999 \mathrm{~b}$ ) with primary tumour cells isolated from resected breast cancer tissue. Here, we report for the first time that PR status and tumour stage are independent predictors of paclitaxel chemosensitivity in primary breast cancer cells.

\section{MATERIALS AND METHODS}

\section{Patients}

We used fresh breast cancer tissue specimens of consecutive patients who underwent surgery for primary breast cancer at the Department of Obstetrics \& Gynecology, University of Mainz, Medical School during October 2002-September 2003. In this period of time, 155 patients had surgery for primary breast cancer. In 53 of these patients, a sufficient amount of fresh breast cancer tissue (at least $0.5 \mathrm{~cm}^{3}$ ) allowed for in vitro chemosensitivity testing. Patient characteristics are shown in Table 1.

\section{In vitro chemosensitivity assay (ATP-TCA)}

The chemosensitivity test was performed with primary tumour cells that have been isolated from tumour tissue immediately after resection. A commercially available kit (TCA-100; DCS, Innovative Diagnostic Systeme, Hamburg, Germany) was used to assess chemosensitivity according to the manufacturer's instructions. Briefly, tumour specimens were dispersed using sterile scalpels. Subsequently, small tissue fragments were enzymatically dissociated. After filtration and ficoll-hypaque density centrifugation, the quality and viability of the single cell suspension were assessed by trypan blue dye exclusion and cytological examination. Adding serum-free Complete Assay Medium (CAM; DCS, Innovative Diagnostic Systeme, Hamburg, Germany) cell suspensions were adjusted to a final concentration of $1-2 \times 10^{5}$ viable cells per ml. Assays for paclitaxel chemosensitivity were performed in 96-well polypropylene microtitre plates. Test drug concentrations were administered in triplicate in six different concentrations: $0.85,1.7$, 3.4, 6.8 and 13.6, $27.2 \mu \mathrm{g} \mathrm{ml}^{-1}$ paclitaxel. Two controls were included for analysis of each tumour, a negative control with complete assay medium (M0) and a positive control containing Maximum ATP Inhibitor (MI, Innovative Diagnostic Systeme, Hamburg, Germany) instead of paclitaxel. Subsequently, $100 \mu \mathrm{l}$ of single cell suspension corresponding to 15000 cells were added to each well. These cultures were then incubated at $37^{\circ} \mathrm{C}$ and $95 \%$ humidity in $5 \% \mathrm{CO}_{2}$ atmosphere. After 6 days of incubation and a cytological analysis of untreated controls, intracellular ATP was extracted and stabilised by addition of $50 \mu$ l tumour cell extraction reagent (TCER; DCS, Innovative Diagnostic Systeme, Hamburg, Germany) to the remaining wells of the culture plates. A $50 \mu \mathrm{l}$ aliquot of each well was then transferred into a luminometer (LB-953 luminometer, Berthold, Wildbad, Germany). After pipetting
Table I Baseline characteristics of the study population

\begin{tabular}{|c|c|c|c|}
\hline & $\begin{array}{l}\text { Number evaluated } \\
\quad(n=50)\end{array}$ & $\%$ & Not evaluable \\
\hline Age (years) & $59.2 \pm 13.5^{\mathrm{a}}$ & & \\
\hline $\begin{array}{c}\text { T-stage } \\
\text { T1 } \\
\text { T2 } \\
\text { T3 } \\
\text { T4 }\end{array}$ & $\begin{array}{r}20 \\
20 \\
3 \\
6\end{array}$ & $\begin{array}{r}40.8 \\
40.8 \\
6.1 \\
12.2\end{array}$ & I \\
\hline $\begin{array}{c}\text { N-stage } \\
\text { N0 } \\
\text { NI } \\
\text { N2 } \\
\text { N3 }\end{array}$ & $\begin{array}{r}20 \\
20 \\
2 \\
5\end{array}$ & $\begin{array}{r}42.6 \\
42.6 \\
4.3 \\
10.6\end{array}$ & 3 \\
\hline $\begin{array}{l}\text { Grading } \\
\text { Grade } 1 \\
\text { Grade 2 } \\
\text { Grade 2 }\end{array}$ & $\begin{array}{r}7 \\
12 \\
31\end{array}$ & $\begin{array}{l}14.0 \\
24.0 \\
62.0\end{array}$ & 0 \\
\hline $\begin{array}{l}\text { Histological type } \\
\text { Invasive ductal carcinoma } \\
\text { Other types }\end{array}$ & $\begin{array}{r}41 \\
8\end{array}$ & $\begin{array}{l}83.7 \\
16.3\end{array}$ & । \\
\hline $\begin{array}{l}\text { Estrogen receptor } \\
\text { Positive } \\
\text { Negative }\end{array}$ & $\begin{array}{l}35 \\
15\end{array}$ & $\begin{array}{l}70.0 \\
30.0\end{array}$ & 0 \\
\hline $\begin{array}{l}\text { Progesterone receptor } \\
\text { Positive } \\
\text { Negative }\end{array}$ & $\begin{array}{l}28 \\
22\end{array}$ & $\begin{array}{l}56.0 \\
44.0\end{array}$ & 0 \\
\hline
\end{tabular}

${ }^{\mathrm{a} M e a n} \pm$ s.d. ${ }^{\mathrm{b}}$ Immunohistochemically determined.

$50 \mu \mathrm{l}$ of luciferin-luciferase reagent (Lu-Lu; DCS, Innovative Diagnostic Systeme, Hamburg, Germany) to each cell extract, the ATP concentration was measured. An ATP standard curve was included into all assays. Three independent incubations with primary tumour cells of each patient were performed with all paclitaxel concentrations $\left(0.85,1.7,3.4,6.8\right.$ and $\left.13.6,27.2 \mu \mathrm{g} \mathrm{ml}^{-1}\right)$, and six independent incubations with the culture medium controls. Median values for each concentration were used to calculate the area under the curve (AUC). From a total of 53 tested breast cancer specimens, three showed a too low ATP content of the culture medium controls after a culture time of 6 days probably owing to a too low viability of the isolated tumour cells. Therefore, the overall evaluability rate was $94 \%$.

\section{Immunohistochemistry}

Serial sections of formalin-fixed slices were stained with either monoclonal ER antibodies (clone 1D5, Dako, Glostrup, Denmark) or monoclonal PR antibodies (clone PgR 636, Dako, Glostrup, Denmark), as described (Steiner et al, 2003). The immunohistochemical evaluation was performed by one of the authors (MS) trained in histological and immunohistochemical diagnostics, unaware of the ATP-TCA data.

\section{Quantitative RT - PCR for PRs A and B}

Total RNA was isolated from $5 \mu \mathrm{M}$ sections of formalin-fixed, paraffin-embedded tumour tissues after histopathological confirmation of a tumour cell content of at least $70 \%$. Reverse transriptase-polymerase chain reaction (RT-PCR) was performed as described Hengstler et al (1999a). Primers and probes were designed for both the exclusive detection of the PR-B isoform as well as the simultaneous detection of the PR-A and PR-B isoforms using the Primer Express software (Applied Biosystems, Foster 
City, CA, USA). Sequences of probe, forward and reverse primer for (i) PGR (isoform B) and (ii) PGR (isoform A+B) were:

(i) Probe: $5^{\prime}$ TCGCAGCAGGAGAAACTTGAAAGCATTC $3^{\prime}$ Forward: $5^{\prime}$ TCAAGAGGAGCAGGACATGTTG $3^{\prime}$ Reverse: 5 TCAAGAGGAGCAGGACATGTTG $3^{\prime}$

(ii) Probe: $5^{\prime}$ TTGATAGAAACGCTGTGAGCTCGA $3^{\prime}$ Forward: $\quad 5^{\prime}$ AGCTCATCAAGGCAATTGGTTT $3^{\prime}$ Reverse:

To standardise the amount of sample RNA, GAPDH was selected as a reference gene. Primer and probes were obtained from Eurogentec s.a. (Liege, Belgium) and the sequences are shown above.

\section{Statistical analysis}

The Statistical Package for Social Science (SPSS 12.0, Inc., Chicago, IL, USA) was used for statistical analysis. Differences between AUC values between two groups were evaluated using the $t$-test. Local significance was considered as two-sided $P<0.05$. Linear regression analysis was used to model dependence of chemosensitivity (AUC) on multiple covariates.

\section{RESULTS}

\section{Paclitaxel chemosensitivity is associated with PR status and tumour stage}

For evaluation of paclitaxel chemosensitivity primary tumour cells isolated from 50 breast cancer patients were analysed (baseline characteristics: Table 1). The area under the dose-response curve (AUC) was used as a measure for chemosensitivity. Representative examples of a relatively sensitive and a relatively resistant tumour as well as the frequency distribution of all AUCs are shown in Figure 1. Next we analysed whether the AUC corresponds to the progesterone and ER status (positive $v s$ negative), as well as to Tstage (stages 3 and $4 v s 1$ and 2), N-stage (stages 1, 2, 3 vs 0 ), grading (grade $3 v s 1$ and 2) and age (older $v s$ younger than 60 years) (Figure 2). A clear association was observed between PR status and the AUC $(P=0.008)$, whereby a positive receptor status was associated with decreased chemosensitivity (Figure 2 ). Similarly, T-stage was associated with chemosensitivity to paclitaxel. Tstage 3 and 4 carcinomas had lower AUCs compared with T-stage 1 and $2(P=0.013)$. In contrast, ER status, $\mathrm{N}$-stage, grading and age were not associated with chemosensitivity to paclitaxel (Figure 2). Similar results were obtained when the IC $_{90}$ was applied for evaluation instead of the AUC (data not shown).

\section{Multiple regression analysis identifies $P R$ status and $T$ -} stage as independent predictors of paclitaxel chemosensitivity

To analyse which of the individual parameters shown in Figure 2 are independent predictors of paclitaxel chemosensitivity, we performed a multiple linear regression analysis. Using a step down approach, initially the $\mathrm{PR}$ status, $\mathrm{T}$-stage, $\mathrm{N}$-stage, grading and age were included. The final model included only PR status (positive $v s$ negative, $P=0.015$ ) and T-stage (stages 3 and $4 v s 1$ and 2, $P=0.021)$ as independent parameters of influence $(P=0.014)$.

\section{PR-A and -B isoforms both are associated with paclitaxel chemosensitivity}

Next, we studied whether the correlation between paclitaxel chemosensitivity and PR status could be confirmed on the mRNA level. In accordance with previous studies we performed quantitative RT-PCR using a primer pair specific for PR-B and another

primer pair amplifying both, PR-A and -B. High-quality RNA could be isolated from only 46 of the 50 patients. mRNA expression of PR-A and $-\mathrm{B}$ as well as of PR-B alone were dichotomised using the respective medians as cutpoints. Both, PR$\mathrm{A}$ and -B as well as PR-B alone were associated with chemosensitivity to paclitaxel ( $P=0.007$ and $P=0.022$, respectively), whereby tumours with relatively high levels of receptor expression appeared less sensitive to paclitaxel compared with carcinomas with low levels of the PR (Figure $3 \mathrm{~A}$ and $\mathrm{B}$ ). Thus, RT-PCR analysis (Figure 3) confirmed the correlation between the immunohistochemically (Figure 2A) determined PR expression and paclitaxel chemosensitivity. The difference in chemosensitivity seems to be slightly higher if PR-A and -B expression (Figure 3A) was considered compared to PR-B alone (Figure $3 \mathrm{~B}$ ), suggesting that PR-A might be more relevant than $\mathrm{PR}-\mathrm{B}$ with respect to chemosensitivity. However, owing to the relatively small difference and owing to the fact that we did not specifically quantify PR-A, conclusions as to possible differences between PR isoforms should be treated with caution. In conclusion, the association of the PR with paclitaxel chemosensitivity could be confirmed on the mRNA level.
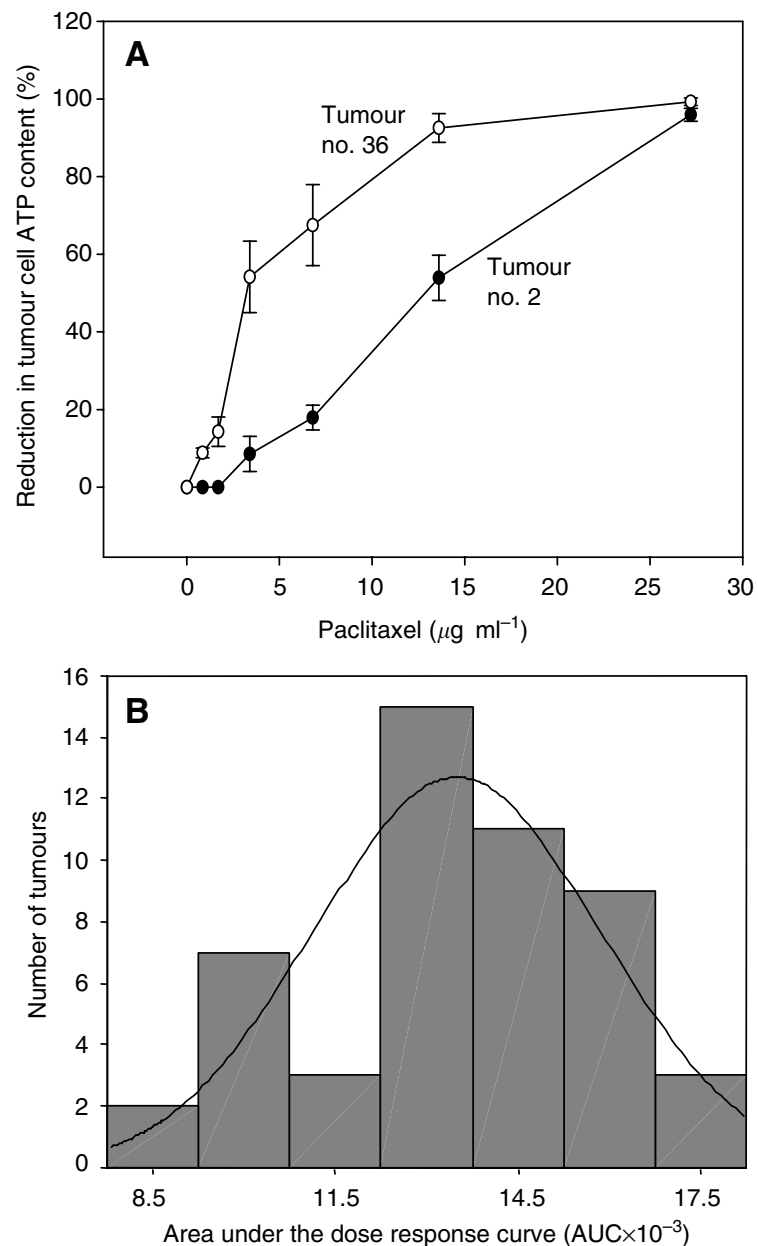

Figure I (A) Representative results of the in vitro chemosensitivity assay. Tumour no. 36 is relatively sensitive (AUC: I6.6) in contrast to tumour no. 2 (AUC: 9.5). A concentration of $3.7 \mu \mathrm{g} \mathrm{ml}^{-1}$ paclitaxel corresponds to the peak plasma concentration reached in patients. All data points are mean values and standard deviations from three independent incubations. (B) Frequency distribution of the AUCs of all 50 tumours. 

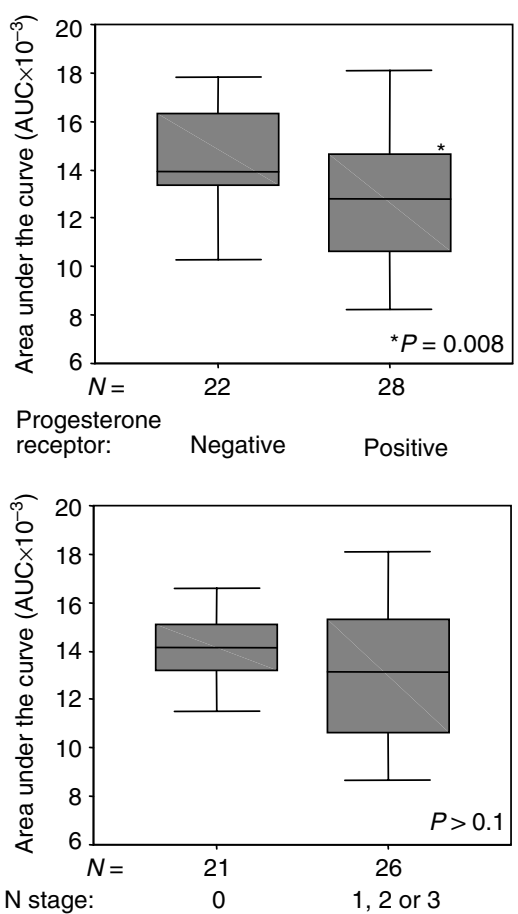
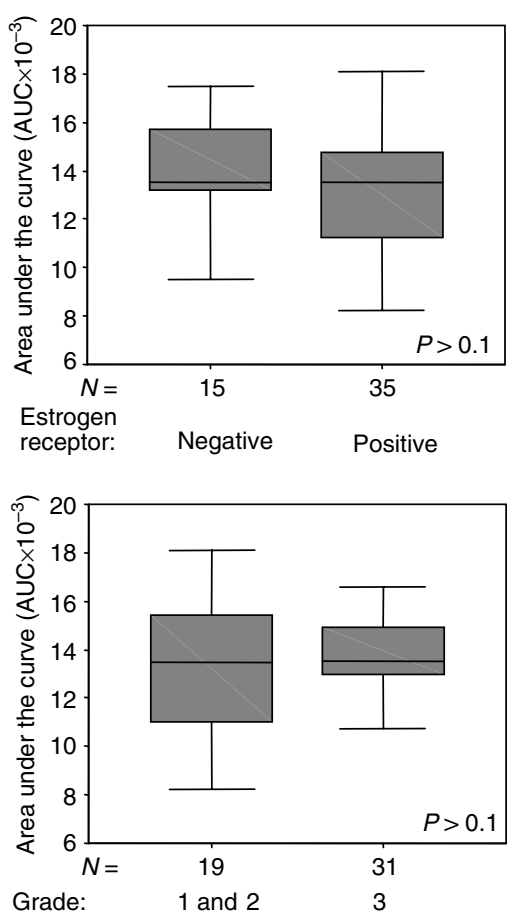
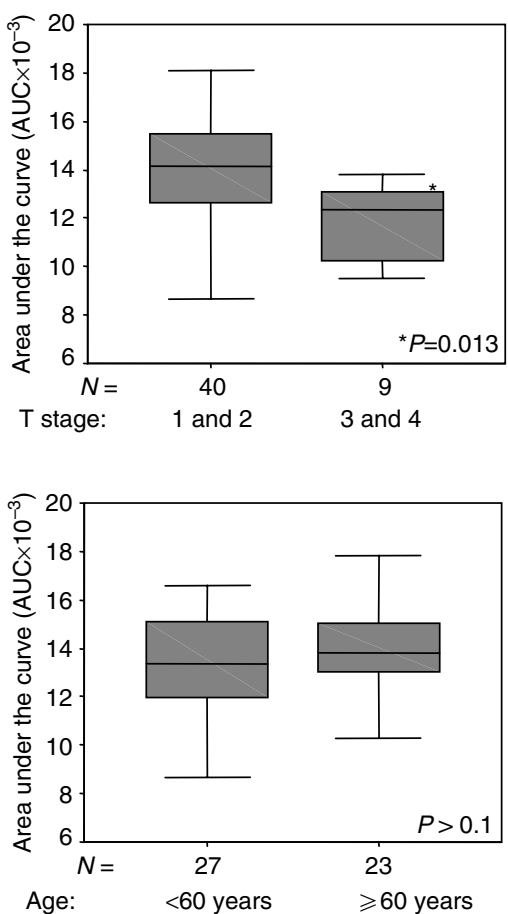

Figure 2 Association between chemosensitivity to paclitaxel (expressed as AUC) and histopathological parameters. Only the progesterone receptor (PR) status $(P=0.008)$ and T-stage $(P=0.013)$ correlated with chemosensitivity.

\section{Influence of PR status and T-stage on paclitaxel dose- response curves}

To be able to quantitatively assess the association of PR status with paclitaxel chemosensitivity we separately analysed tumour cells from T-stage 1 or 2 as well as T-stage 3 or 4 patients. In the group of T-stage 1 or 2 tumours a higher sensitivity was observed for the PR-negative cells (Figure 4A). The difference in the AUC between PR-negative and -positive cells in T-stage 1 or 2 was significant $(P=0.027)$. A similar association between $\mathrm{PR}$ and sensitivity to paclitaxel was seen in cells from T-stage 3 or 4 tumours (Figure $4 \mathrm{~B}$, $P=0.049$ ). The largest difference was obtained between PRnegative/T-stage 1 or 2 vs PR-positive/T-stage 3 or 4 tumours (Figure $4 \mathrm{C}, P=0.001$ ). In the concentration range between 1.7 and $3.4 \mu \mathrm{g} \mathrm{ml}^{-1}$ approximately two-fold higher concentrations of paclitaxel are required for PR positive/T-stage 3 or 4 tumours to achieve a toxicity similar to that as for PR-negative/T-stage 1 or 2 tumours.

\section{DISCUSSION}

Selecting patients with primary breast cancer for the most appropriate adjuvant systemic treatment is of great importance. The only currently accepted and reliable predictive factor for clinical decision making in the adjuvant setting is the hormone receptor status (Goldhirsch et al, 2005). Besides hormone receptors, there is no generally accepted factor for the prediction of response to chemotherapy in breast cancer. HER-2/neu was retrospectively investigated as a predictive factor for an anthracycline-based therapy in comparison with CMF (Paik et al, 1998; Moliterni et al, 2003). However, owing to inconsistent results, HER-2/neu is currently not recommended in this setting (Goldhirsch et al, 2005). In an explorative subgroup analysis of the randomised clinical trial CALGB 9344, Henderson et al (2003) observed evidence that the ER status might be predictive for a benefit of paclitaxel added to a standard anthracyclin-based regimen. Patients with ER-positive tumours had a greater benefit from the addition of paclitaxel to an anthracycline-based therapy than patients with ER-negative tumours. However, based on this finding, it is unclear whether this is truly predictive for paclitaxel response or whether the well-known prognostic effects of the hormone receptor status itself come into play. Other clinical trials also investigated a possible interaction between the ER status and paclitaxel (Mamounas et al, 2005) or docetaxel (Nabholtz et al, 2002). However, these trials failed to demonstrate any interaction between clinical outcome and ER expression.

For the above mentioned reasons, the adjuvant setting is not ideal to investigate the predictive effect of a biomarker. A design which is much more appropriate for this particular purpose was used in the National Surgical Adjuvant Breast and Bowel Project Protocol (NSABP) B-27. In this clinical trial, patients with primary breast cancer were treated with primary systemic chemotherapy either with or without docetaxel. These authors again failed to confirm any association between the ER status and the benefit from the use of a taxane containing regimen. However, owing to the concurrent administration of tamoxifen and chemotherapy, the potential predictive effect of the ER for chemotherapy response might be obscured.

In the present study, we excluded potential prognostic effects as well as interference with other systemic therapies by using a wellestablished in vitro assay (ATP-TCA) for primary tumour cells (Andreotti et al, 1995; Cree et al, 1996; Kurbacher et al, 1996; Hengstler et al, 1999b; Konecny et al, 2000) in a consecutive series of 53 primary breast cancers. The ATP-TCA has been shown to allow a prediction of clinical results. The ATP-TCA-directed chemotherapy has improved clinical outcome in several studies (Andreotti et al, 1995; Cree et al, 1996; Kurbacher et al, 1996; Konecny et al, 2000). It should be considered that our ATP assay measures chemosensitivity on a cellular level, which is only one of several parameters relevant for clinical outcome. Other relevant parameters, such as local pharmacokinetics, tumour vascularisation, oxygen supply or immune response will not be considered by 

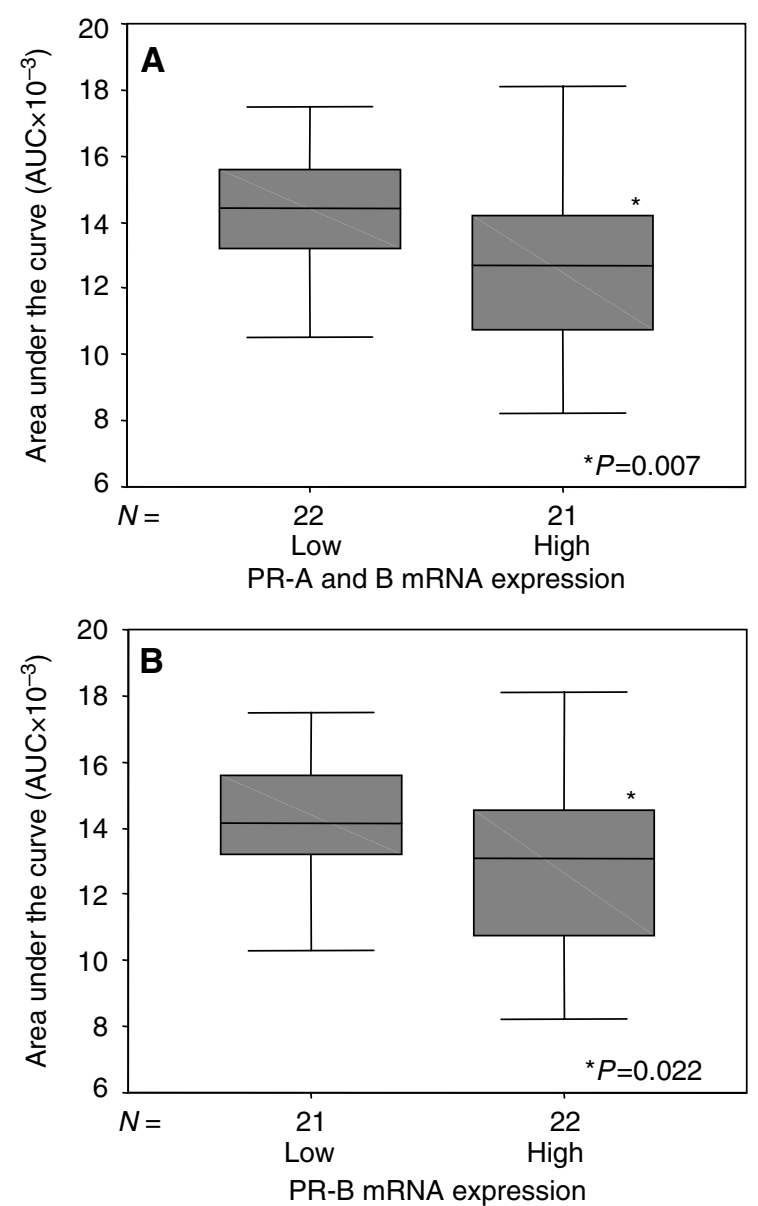

Figure 3 Association between paclitaxel chemosensitivity and PR mRNA expression. High expression of PR-A + B $(\mathbf{A})$ and PR-B $(\mathbf{B})$ mRNA expression is associated with decreased sensitivity (AUC) of the breast cancer cells to paclitaxel.

our in vitro technique. Nevertheless, the applied assay determines whether tumour cells ex vivo dispose of mechanisms protecting them from paclitaxel toxicity in vitro. This is likely to be one of several parameters contributing to chemosensitivity of a tumour in vivo. Our assay evaluability rate of $94 \%$ is well in line with the literature (Cree et al, 1996; Kurbacher et al, 1996). The present study was designed to study a possible association of ER and PR status with chemosensitivity of breast cancer cells in the ATP-TCA and to analyse whether a possible association is independent from the classical clinical factors, such as T-stage, $\mathrm{N}$-stage, grading and age.

In the present prospective study, we observed a clear association between the PR status and chemosensitivity to paclitaxel. Higher levels of immunohistochemically detected PR expression correlated with decreased chemosensitivity. To confirm this observation by a second, independent technique, we measured PR expression also by quantitative RT-PCR. Progesterone exerts its effects through two nuclear receptors, PR-A and PR-B, which are encoded by a single gene, under the regulation of two distinct promoters (Kastner et al, 1990). The two receptor proteins are identical except that PR-B contains an additional 164 amino acids at its $\mathrm{N}$-terminal end that are absent from PR-A. These two PR isoforms can be distinguished by immunoblot analysis, but not by ligandbinding assays or by immunohistochemistry. In accordance with previous studies, we used two pairs of primers amplifying either a fragment of the identical part (PR-A and -B) as well as a fragment

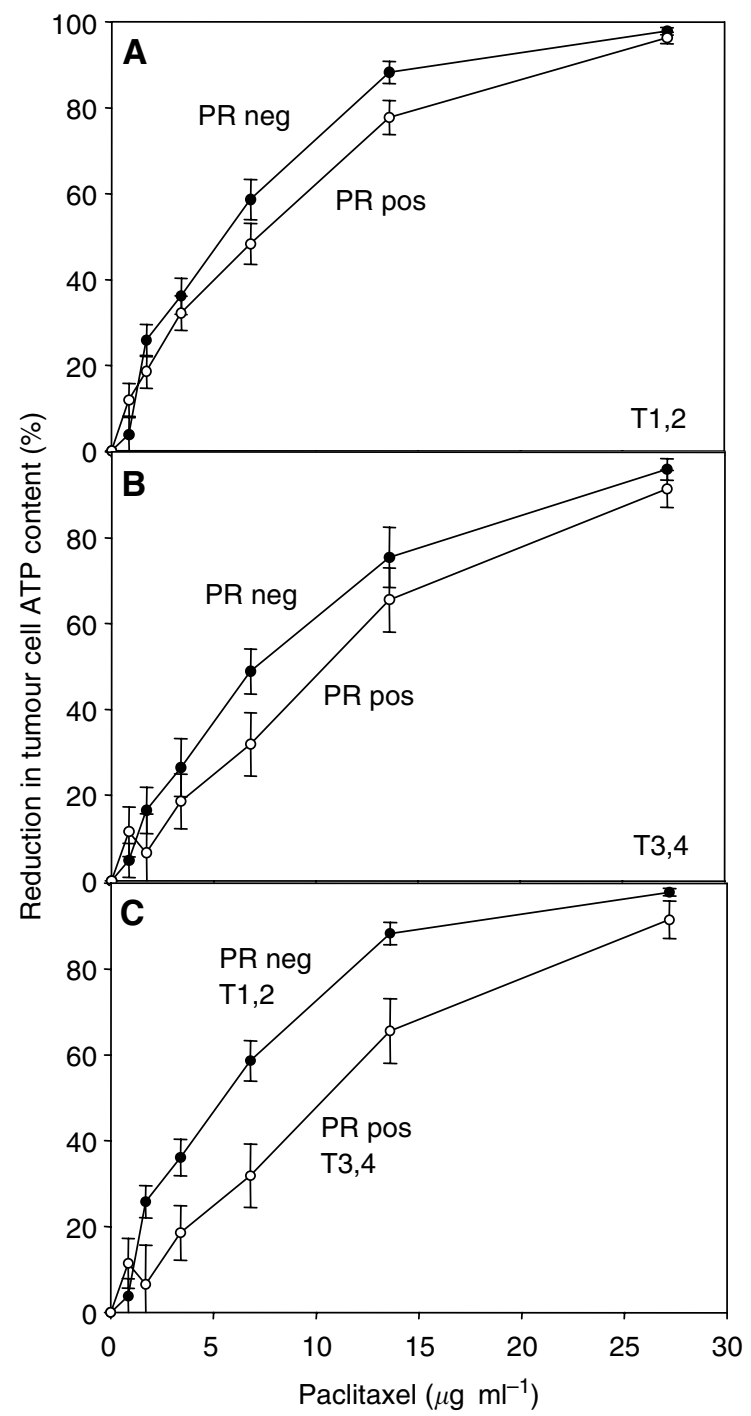

Figure 4 Sensitivity of primary breast cancer cells from 50 patients to paclitaxel. (A) Influence of the progesterone receptor (PR) status in primary tumour cells from patients with T-stage I or 2. (B) Influence of the PR status in primary tumour cells from patients with T-stage 3 and 4. (C) Combined influence of PR status and T-stage: patients with PR-negative tumours, T-stage I or 2 vs patients with PR-positive tumours, T-stage 3 or 4. The difference between the two groups was significant $(P<0.0 \mathrm{I})$ for paclitaxel concentrations of $1.7,3.4,6.8$ and $\mid 3.6 \mu \mathrm{g} \mathrm{ml}^{-1}$. In contrast, no significant difference was obtained for the highest concentration of $27.2 \mu \mathrm{g} \mathrm{ml}^{-1}$ paclitaxel.

specific for PR-B. Similar to the result obtained by immunohistochemistry, PR mRNA expression also correlated with chemosensitivity. A high correlation of the two isoforms with each other and also with total PR has been reported, indicating that virtually every PR-positive breast tumour expresses at least some level of PR-A and -B (Hopp et al, 2004). In our study, both, PR-A and -B and PR-B mRNA expression correlated with decreased chemosensitivity to paclitaxel.

We did not address the question of the molecular mechanisms responsible for PR-mediated chemoresistance in the present study. However, previous studies have demonstrated an up regulation of the antiapoptotic gene BCL-XL in breast cancer cells as a consequence of PR-A expression (Richer et al, 2002). This upregulation could lead to resistance to apoptosis. As apoptosis is a major factor for the cytotoxic effects exerted by paclitaxel 
(Woods et al, 1995; Milross et al, 1996), it might explain why PR-positive tumours were more resistant to paclitaxel compared with PR-negative carcinomas. However, besides BCL-XL, at least 93 further genes have been shown to be PR-A and/ or PR-B dependent in breast cancer cells (Richer et al, 2002). Therefore, it can not be excluded that PR-mediated chemoresistance is multifactorial, whereby BCL-XL may represent only one of several factors. Nevertheless, the antiapoptotic influence of the PR is well documented. For instance, serum depletion-induced apoptosis was inhibited by progesterone treatment (Ory et al, 2001) and also radiation-induced apoptosis could be antagonised via PR (Vares et al, 2004) in breast cancer cell lines.

Using multiple regression analysis we demonstrated that an association of the PR with paclitaxel chemosensitivity is independent from classical clinical prognostic factors. However, a second factor was found to be influential, namely the T-stage. To be able to quantitatively assess the association of PR status with T-stage, we compared the dose-effect curves of four subgroups tumours: (i) PR negative and T-stage 1 or 2, (ii) PR negative and T-stage 3 or 4, (iii) PR positive and T-stage 1 or 2 and (iv) PR positive and T-stage 3 or 4 . Tumours of PR-negative/T-stage 1 or 2 tumours were clearly more sensitive than PR-positive/T-stage 3 or 4 tumours. The concentrations used in our in vitro study are 0 , $0.85,1.7,3.4,6.8$ and $13.6,27.2 \mu \mathrm{g} \mathrm{ml}^{-1}$ paclitaxel. The choice of these concentrations is based on pharmacokinetic data of a phase 3 randomised study following 3- and 24-h infusions of paclitaxel at dose levels of 135 and $175 \mathrm{mg} \mathrm{m}^{-2}$. Maximum plasma concentrations were $3.65 \mu \mathrm{g} \mathrm{ml}^{-1}$ for $3 \mathrm{~h}$ infusion of $175 \mathrm{mg} \mathrm{m}^{-2}$ paclitaxel. Therefore, a clinically relevant dose range has been chosen in the present study. In this range of clinically relevant concentrations, approximately two-fold higher concentrations are required for PR-positive/T-stage 3 or 4 tumours to achieve a similar toxicity compared to PR-negative/T-stage 1 or 2 tumours. It is likely that both PR and T-stage are only two of many factors influencing paclitaxel sensitivity of breast cancer. Nevertheless, the results of this study demonstrate that PR and T-stage should be considered as influential parameters in studies aimed at identifying new factors that might predict paclitaxel resistance.

In conclusion, our prospective study in primary breast cancer highlights the importance of the PR for the chemosensitivity to paclitaxel. Clearly, these ex vivo data should be taken as hypothesis-generating results which have to be confirmed in larger clinical trials.

\section{ACKNOWLEDGEMENTS}

This study was supported by the German Research Foundation (DFG).

\section{REFERENCES}

Andreotti PE, Cree IA, Kurbacher CM, Hartmann DM, Linder D, Harel G, Gleiberman I, Caruso PA, Ricks SH, Untch M (1995) Chemosensitivity testing of human tumors using a microplate adenosine triphosphate luminescence assay: clinical correlation for cisplatin resistance of ovarian carcinoma. Cancer Res 55: 5276-5282

Brenner W, Farber G, Herget T, Lehr HA, Hengstler JG, Thuroff JW (2002) Loss of tumor suppressor protein PTEN during renal carcinogenesis. Int J Cancer 99: 53-57

Chang JC, Wooten EC, Tsimelzon A, Hilsenbeck SG, Gutierrez MC, Elledge R, Mohsin S, Osborne CK, Chamness GC, Allred DC, O’Connell P (2003) Gene expression profiling for the prediction of therapeutic response to docetaxel in patients with breast cancer. Lancet 362: $362-369$

Cree IA, Kurbacher CM, Untch M, Sutherland LA, Hunter EM, Subedi AM, James EA, Dewar JA, Preece PE, Andreotti PE, Bruckner HW (1996) Correlation of the clinical response to chemotherapy in breast cancer with ex vivo chemosensitivity. Anticancer Drugs 7: 630-635

Di Nicolantonio F, Knight LA, Glaysher S, Whitehouse PA, Mercer SJ, Sharma S, Mills L, Prin A, Johnson P, Charlton PA, Norris D, Cree IA (2004) Ex vivo reversal of chemoresistance by tariquidar (XR9576) Anticancer Drugs 15: $861-869$

Duan Z, Lamendola DE, Duan Y, Yusuf RZ, Seiden MV (2005) Description of paclitaxel resistance-associated genes in ovarian and breast cancer cell lines. Cancer Chemother Pharmacol 55: 277-285

Goldhirsch A, Glick JH, Gelber RD, Coates AS, Thurlimann B, Senn HJ (2005) Meeting highlights: international expert consensus on the primary therapy of early breast cancer 2005. Ann Oncol 16: 1569-1583

Hast J, Schiffer IB, Neugebauer B, Teichman E, Schreiber W, Brieger J, Kim DW, Gebhard S, Born CJ, Strugala M, Sagemuller J, Brenner W, Mann WJ, Oesch F, Thelen M, Hengstler JG (2002) Angiogenesis and fibroblast proliferation precede formation of recurrent tumors after radiation therapy in nude mice. Anticancer Res 22: 677-688

Henderson IC, Berry DA, Demetri GD, Cirrincione CT, Goldstein LJ, Martino S, Ingle JN, Cooper MR, Hayes DF, Tkaczuk KH, Fleming G, Holland JF, Duggan DB, Carpenter JT, Frei III E, Schilsky RL, Wood WC, Muss HB, Norton L (2003) Improved outcomes from adding sequential paclitaxel but not from escalating doxorubicin dose in an adjuvant chemotherapy regimen for patients with node-positive primary breast cancer. J Clin Oncol 21: 976-983

Hengstler JG, Fuchs J, Oesch F (1992) DNA strand breaks and DNA crosslinks in peripheral mononuclear blood cells of ovarian cancer patients during chemotherapy with cyclophosphamide/carboplatin. Cancer Res 52: $5622-5626$
Hengstler JG, Lange J, Kett A, Dornhofer N, Meinert R, Arand M, Knapstein PG, Becker R, Oesch F, Tanner B (1999a) Contribution of c-erbB-2 and topoisomerase IIalpha to chemoresistance in ovarian cancer. Cancer Res 59: $3206-3214$

Hengstler JG, Lange J, Kett A, Dornhofer N, Meinert R, Arand M, Knapstein PG, Becker R, Oesch F, Tanner B (1999b) Contribution of c-erbB-2 and topoisomerase IIalpha to chemoresistance in ovarian cancer. Cancer Res 59: $3206-3214$

Hengstler JG, Pilch H, Schmidt M, Dahlenburg H, Sagemuller J, Schiffer I, Oesch F, Knapstein PG, Kaina B, Tanner B (2001) Metallothionein expression in ovarian cancer in relation to histopathological parameters and molecular markers of prognosis. Int J Cancer 95: $121-127$

Hopp TA, Weiss HL, Hilsenbeck SG, Cui Y, Allred DC, Horwitz KB, Fuqua SA (2004) Breast cancer patients with progesterone receptor PRA-rich tumors have poorer disease-free survival rates. Clin Cancer Res 10: $2751-2760$

Kastner P, Krust A, Turcotte B, Stropp U, Tora L, Gronemeyer H, Chambon P (1990) Two distinct estrogen-regulated promoters generate transcripts encoding the two functionally different human progesterone receptor forms A and B. EMBO J 9: 1603-1614

Konecny G, Crohns C, Pegram M, Felber M, Lude S, Kurbacher C, Cree IA, Hepp H, Untch M (2000) Correlation of drug response with the ATP tumorchemosensitivity assay in primary FIGO stage III ovarian cancer. Gynecol Oncol 77: 258-263

Kurbacher CM, Cree IA, Brenne U, Bruckner HW, Kurbacher JA, Mallmann P, Andreotti PE, Krebs D (1996) Heterogeneity of in vitro chemosensitivity in perioperative breast cancer cells to mitoxantrone $v s$ doxorubicin evaluated by a microplate ATP bioluminescence assay. Breast Cancer Res Treat 41: $161-170$

Mamounas EP, Bryant J, Lembersky B, Fehrenbacher L, Sedlacek SM, Fisher B, Wickerham DL, Yothers G, Soran A, Wolmark N (2005) Paclitaxel after doxorubicin plus cyclophosphamide as adjuvant chemotherapy for node-positive breast cancer: results from NSABP B28. J Clin Oncol 23: $3686-3696$

Micke P, Basrai M, Faldum A, Bittinger F, Ronnstrand L, Blaukat A, Beeh KM, Oesch F, Fischer B, Buhl R, Hengstler JG (2003) Characterization of c-kit expression in small cell lung cancer: prognostic and therapeutic implications. Clin Cancer Res 9: 188-194

Micke P, Hengstler JG, Ros R, Bittinger F, Metz T, Gebhard S, Beeh KM, Oesch F, Buhl R (2001) c-erbB-2 expression in small-cell lung cancer is associated with poor prognosis. Int J Cancer 92: 474-479 
Milross CG, Mason KA, Hunter NR, Chung WK, Peters LJ, Milas L (1996) Relationship of mitotic arrest and apoptosis to antitumor effect of paclitaxel. J Natl Cancer Inst 88: 1308 - 1314

Mohrmann G, Hengstler JG, Hofmann TG, Endele SU, Lee B, Stelzer C, Zabel B, Brieger J, Hasenclever D, Tanner B, Sagemueller J, Sehouli J, Will H, Winterpacht A (2005) SPOC1, a novel PHD-finger protein: association with residual disease and survival in ovarian cancer. Int $J$ Cancer 116: $547-554$

Moliterni A, Menard S, Valagussa P, Biganzoli E, Boracchi P, Balsari A, Casalini P, Tomasic G, Marubini E, Pilotti S, Bonadonna G (2003) HER2 overexpression and doxorubicin in adjuvant chemotherapy for resectable breast cancer. J Clin Oncol 21: $458-462$

Nabholtz JM, Cantin J, Chang J, Guevin R, Patel R, Tkaczuk K, Vodvarka P, Lindsay MA, Reese D, Riva A, Mackey J (2002) Phase III trial comparing granulocyte colony-stimulating factor to leridistim in the prevention of neutropenic complications in breast cancer patients treated with docetaxel/doxorubicin/cyclophosphamide: results of the BCIRG 004 trial. Clin Breast Cancer 3: 268-275

Ory K, Lebeau J, Levalois C, Bishay K, Fouchet P, Allemand I, Therwath A, Chevillard S (2001) Apoptosis inhibition mediated by medroxyprogesterone acetate treatment of breast cancer cell lines. Breast Cancer Res Treat 68: $187-198$

Paik S, Bryant J, Park C, Fisher B, Tan-Chiu E, Hyams D, Fisher ER, Lippman ME, Wickerham DL, Wolmark N (1998) erbB-2 and response to doxorubicin in patients with axillary lymph node-positive, hormone receptor-negative breast cancer. J Natl Cancer Inst 90: 1361 - 1370

Paradiso A, Mangia A, Chiriatti A, Tommasi S, Zito A, Latorre A, Schittulli F, Lorusso V (2005) Biomarkers predictive for clinical efficacy of taxol-based chemotherapy in advanced breast cancer. Ann Oncol 16(Suppl 4): iv14-iv19
Richer JK, Jacobsen BM, Manning NG, Abel MG, Wolf DM, Horwitz KB (2002) Differential gene regulation by the two progesterone receptor isoforms in human breast cancer cells. J Biol Chem 277: 5209-5218

Rouzier R, Rajan R, Wagner P, Hess KR, Gold DL, Stec J, Ayers M, Ross JS, Zhang P, Buchholz TA, Kuerer H, Green M, Arun B, Hortobagyi GN, Symmans WF, Pusztai L (2005) Microtubule-associated protein tau: a marker of paclitaxel sensitivity in breast cancer. Proc Natl Acad Sci USA 102: $8315-8320$

Schiffer IB, Gebhard S, Heimerdinger CK, Heling A, Hast J, Wollscheid U, Seliger B, Tanner B, Gilbert S, Beckers T, Baasner S, Brenner W, Spangenberg C, Prawitt D, Trost T, Schreiber WG, Zabel B, Thelen M, Lehr HA, Oesch F, Hengstler JG (2003) Switching off HER-2/neu in a tetracycline-controlled mouse tumor model leads to apoptosis and tumor-size-dependent remission. Cancer Res 63: 7221 - 7231

Steiner E, Eicher O, Sagemuller J, Schmidt M, Pilch H, Tanner B, Hengstler JG, Hofmann M, Knapstein PG (2003) Multivariate independent prognostic factors in endometrial carcinoma: a clinicopathologic study in 181 patients: 10 years experience at the Department of Obstetrics and Gynecology of the Mainz University. Int J Gynecol Cancer 13: $197-203$

Sudo T, Nitta M, Saya H, Ueno NT (2004) Dependence of paclitaxel sensitivity on a functional spindle assembly checkpoint. Cancer Res 64: $2502-2508$

Vares G, Ory K, Lectard B, Levalois C, Altmeyer-Morel S, Chevillard S, Lebeau J (2004) Progesterone prevents radiation-induced apoptosis in breast cancer cells. Oncogene 23: $4603-4613$

Woods CM, Zhu J, McQueney PA, Bollag D, Lazarides E (1995) Taxolinduced mitotic block triggers rapid onset of a p53-independent apoptotic pathway. Mol Med 1: 506-526 